\title{
Optimization of Membrane Reverse Osmosis separation for Aqueous media characterized by High mineralization
}

\author{
T.A.Trifonova ${ }^{1}$, A.A. Povorov ${ }^{2}$ A.A., L.A. Shirkin ${ }^{3}$, O.G. Selivanov ${ }^{4}$, M.E Ilina ${ }^{5}$ \\ ${ }^{1}$ Vladimir State University named after A. G. and N. G. Stoletovs, Vladimir, Russian Federation \\ tatrifon@mail.ru \\ ${ }^{2}$ BMT LLC, Vladimir, Russian Federation \\ vladimir@vladbmt.ru \\ ${ }^{3}$ Vladimir State University named after A. G. and N. G. Stoletovs, Vladimir, Russian Federation \\ shirkin76@mail.ru \\ ${ }^{4}$ Vladimir State University named after A. G. and N. G. Stoletovs, Vladimir, Russian Federation, \\ selivanov6003@mail.ru \\ ${ }^{5}$ Vladimir State University named after A. G. and N. G. Stoletovs, Vladimir, Russian Federation \\ ilina4@mail.ru
}

\begin{abstract}
The research highlights the issue of optimization of the membrane reverse osmosis separation for aqueous media characterized by high content of hardness salts. The pilot two-stage reverse osmosis plant was applied for the research. To improve the process of membrane reverse osmosis separation, antiscalants Avista Vitec 3000, Clarofos 381 and sodium tripolyphosphate were used. Waste water from a solid waste landfill, characterized by increased hardness, was used as the studied aqueous solution. The effectiveness of antiscalants impact on the process of membrane reverse osmosis separation was assessed basing on the membrane specific performance. The studies have shown that to select the right antiscalant, it is necessary to take into account the characteristics of the fed water composition, the operating mode of the membrane equipment and special requirements of the treatment technology.
\end{abstract}

Key words: membrane separation, two-stage reverse osmosis plant, highly concentrated waste water, hardness salts, antiscalant, membrane specific performance, concentration degree.

\section{INTRODUCTION}

Nowadays, one of the most advanced water desalination technologies is reverse osmosis (RO) membrane separation of aqueous media. The applied RO plants ensure high quality water treatment throughout the entire effective life of the membrane equipment. However, RO technologies advancement does not comprise only developing membrane materials, RO plant design and RO process optimizing. In RO systems performance considerable role belongs to pretreatment of the fed aqueous media. The membranes service life before replacement is known to be determined mainly by their performance decrease, which in turn separation, the operating mode of the membrane equipment and treatment technology requirements [1-2]. Problems of membranes performance reduction in $\mathrm{RO}$ plants can be solved by increasing their efficiency by proper pre-treatment options for aqueous media, which can significantly reduce organic and inorganic contamination of the membranes, by selective decontamination prior the RO plant [3-4].

Hardness salts, contained in aqueous media, particularly affect scaling process on the filter elements [57]. Hardness salts, represented by the compounds of calcium, magnesium (much rarely of strontium, barium) in the form of carbonates, bicarbonates and sulfates, when scaling on the membrane element surface form insoluble crystal formations, thereby significantly reducing the membrane element performance.

These impurities can be removed at the stage of water pre-treatment, for example, using ion exchange filters, but in many cases this solution is not effective enough and economically feasible.

To ensure stable operation of the membrane equipment during desalination of water or highly mineralized solutions, special chemicals - antiscalants are used, which significantly slow down the scaling process on the membrane surface. antiscalants application allows significant increase of the RO membrane elements service life, which are widely used for the treatment of highly mineralized water from solid waste landfills, natural underground water, sea water, district and make-up water for heating systems in the fuel and energy enterprises, etc.

The research objective is to select the optimal aniscalant for membrane separation of the pre-treated solid waste landfill leachate characterized by the increased hardness.

\section{RESEARCH OBJECTS AND METHODS}

The antiscalant selection for optimizing the process of membrane separation of the pre-treated leachate from solid waste landfill "Maryinsky" (Vladimir region) was carried 
out applying two-stage reverse osmosis membrane plant, developed by BMT ltd, Vladimir, shown in figure 1.

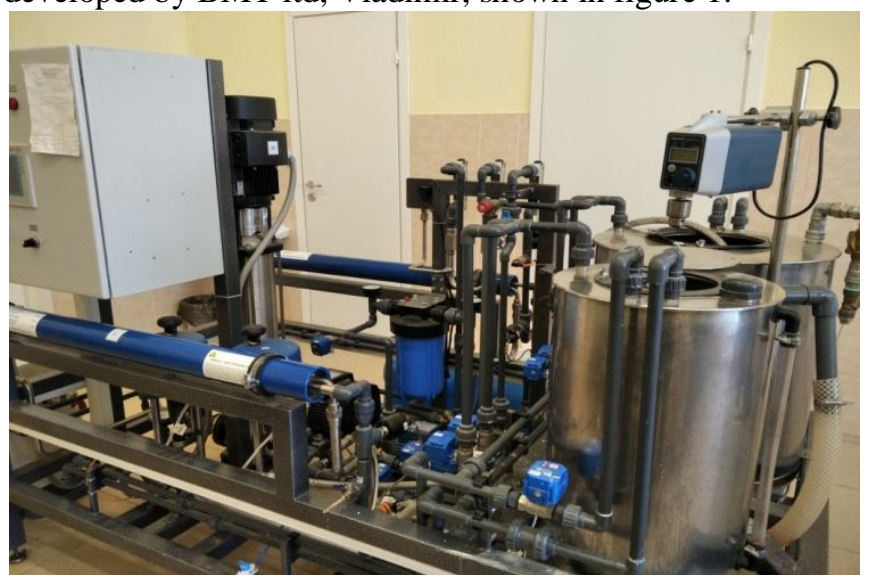

Figure 1: Two-stage reverse osmosis membrane pilot plant.

The membrane element 4040SN was used at the first stage of the RO separation plant for landfill leachate, and membrane element RE 4040BL, produced by CSM (South Korea), was used at the second stage of the RO plant.

The analysis of the available data concerning the leachate chemical composition from various landfills showed that leachate from almost all solid waste landfills possess fairly high index of total hardness. Therefore, the selection of the optimal type of antiscalant for membrane separation of aqueous media with the increased mineralization is an important task for RO plants.

In the course of the experiments the following antiscalants were considered and tested: Avista Vitec 3000, Clarofos 381 and sodium tripolyphosphate.

To assess their impact on the landfill leachate membrane concentration, a series of comparative tests was conducted at the first stage of membrane purification without using of inhibitors and with them. Preliminary acidification of fed water up to $\mathrm{pH}=7$ was performed in every experiment.

For the integrity of test, chemical washing was performed for the membrane element after each concentration process to restore its transport characteristics.

The determination of hydrogen index $(\mathrm{pH})$ of the fed water was carried out using environmental standard ENS F 14.1:2:3:4.121-97, total hardness determination of aqueous media according to ENS F 14.1:2.98-97.

The principal parameters of pre-treated leachate, used in the experiments at RO plant, are shown in table 1.

Table 1: Principal parameters of pre-treated landfill leachate

\begin{tabular}{|l|c|}
\hline \multicolumn{1}{|c|}{$\begin{array}{c}\text { Indicators, measurement } \\
\text { units }\end{array}$} & $\begin{array}{c}\text { Parameters value of pre- } \\
\text { treated fed water }\end{array}$ \\
\hline Hydrogen index $(\mathrm{pH})$ & 9.72 \\
\hline Total hardness, mg-eqv/l & 0.6 \\
\hline Calcium $(\mathrm{Ca}), \mathrm{mg} / \mathrm{l}$ & 6.2 \\
\hline Magnesium $(\mathrm{Mg}), \mathrm{mg} / \mathrm{l}$ & 3.6 \\
\hline Iron $(\mathrm{Fe}), \mathrm{mg} / \mathrm{l}$ & 0.05 \\
\hline Alkalinity, mg-eqv/l & 50.4 \\
\hline Salinity, mg/l & 3000 \\
\hline
\end{tabular}

\section{RESEARCH RESULTS AND DISCUSSION}

The first research stage was devoted to the process of leachate membrane concentration carried out at the pilot RO plant without any antiscalants.

The test conditions corresponded to the previously described conditions for membrane reverse osmosis separation at the first stage of the pilot plant [8]. The initial leachate after pre-treatment at the granular filter, was fed into the initial tank, from which high pressure plunger pump fed it to the first stage of RO plant - the membrane apparatus. At the first stage the waste water was divided into two streams under the operating pressure of up to $60 \mathrm{~atm}$.: purified and partially desalinated water (first stage permeate), collected in the receiving tank, and the first stage concentrate was continuously returned to the initial tank. Reaching the specified degree of permeate selection, the process of waste water concentration was stopped.

During the experiments the dependence of membrane specific performance on the concentration degree during the clarified leachate separation was determined. The experiments results are shown in table 2 .

Table 2: Dependence of membrane specific performance changes on concentration degree without using antiscalant

\begin{tabular}{|c|c|c|c|c|}
\hline $\begin{array}{c}\text { Concent- } \\
\text { ration } \\
\text { period, } \\
\text { min }\end{array}$ & $\mathrm{t},{ }^{\circ} \mathrm{C}$ & $\begin{array}{c}\text { Membrane } \\
\text { element } \\
\text { perfor- } \\
\text { mance, } \\
1 / \mathrm{h}\end{array}$ & $\begin{array}{c}\text { Membrane } \\
\text { specific } \\
\text { perfor- } \\
\text { mance, } \\
1 / \mathrm{m}^{2} \mathrm{~h}\end{array}$ & $\begin{array}{c}\text { Concen- } \\
\text { tration } \\
\text { degree, } \\
\text { times }\end{array}$ \\
\hline 0 & 18 & 129 & 18.4 & 0 \\
\hline 10 & 18 & 115 & 16.4 & 1.1 \\
\hline 25 & 19 & 105 & 15 & 1.2 \\
\hline 40 & 19 & 91 & 13 & 1.33 \\
\hline 55 & 20 & 84 & 12 & 1.4 \\
\hline 60 & 20 & 77 & 11 & 1.5 \\
\hline 80 & 21 & 59 & 8.4 & 1.67 \\
\hline 95 & 21 & 53 & 7.6 & 1.82 \\
\hline 110 & 22 & 45 & 6.4 & 2 \\
\hline 155 & 24 & 35 & 5 & 2.2 \\
\hline 180 & 25 & 18 & 2.6 & 2.9 \\
\hline
\end{tabular}

To assess the impact on the membrane separation process, the chemical Avista Vitec 3000 was tested as antiscalant.

The chemicals dosage was selected in compliance with the manufacturer's recommendations and equaled 3 $\mathrm{mg} / \mathrm{l}$. The chemical in the calculated dosage was introduced into the initial clarified leachate. Then membrane separation was performed at the first stage of the pilot plant under the above described conditions. At the second experimental stage the membrane concentration process of the clarified leachate using antiscalants was carried out.

During the experiments, the dependence of the membrane specific performance on concentration degree was determined. The results are presented in table 3 . 
T.A.Trifonova et al., International Journal of Emerging Trends in Engineering Research, 8(4), April 2020, 1125 - 1128

Table 3:The dependence of membrane specific performance changes on concentration degree using antiscalant Avista Vitec 3000

\begin{tabular}{|c|c|c|c|c|}
\hline $\begin{array}{c}\text { Concen- } \\
\text { tration } \\
\text { period, } \\
\text { min }\end{array}$ & $\mathrm{t},{ }^{\circ} \mathrm{C}$ & $\begin{array}{c}\text { Membrane } \\
\text { element } \\
\text { perfor- } \\
\text { mance, } 1 / \mathrm{h}\end{array}$ & $\begin{array}{c}\text { Membrane } \\
\text { specific } \\
\text { perfor- } \\
\text { mance, } \\
1 / \mathrm{m}^{2} \mathrm{~h}\end{array}$ & $\begin{array}{c}\text { Concen- } \\
\text { tration } \\
\text { degree, } \\
\text { times }\end{array}$ \\
\hline 0 & 14 & 164 & 23.4 & 1 \\
\hline 10 & 15 & 150 & 21.4 & 1.05 \\
\hline 25 & 16 & 140 & 20 & 1.1 \\
\hline 35 & 16.5 & 122 & 17.4 & 1.2 \\
\hline 45 & 17 & 112 & 16 & 1.3 \\
\hline 60 & 18 & 106 & 15.1 & 1.35 \\
\hline 80 & 19 & 101 & 14.4 & 1.4 \\
\hline 95 & 19 & 91 & 13 & 1.5 \\
\hline 115 & 20 & 85 & 12.1 & 1.6 \\
\hline 135 & 21 & 80 & 11.3 & 1.7 \\
\hline 150 & 22 & 70 & 10 & 1.9 \\
\hline 170 & 22 & 59 & 8.4 & 2 \\
\hline 200 & 24 & 46 & 6.6 & 2.2 \\
\hline 235 & 26 & 39 & 5.6 & 2.3 \\
\hline 245 & 27 & 29 & 4.1 & 2.7 \\
\hline
\end{tabular}

The final concentration degree was in 2.7 times.

The following antiscalant - Clarofos 381 was tested to assess its effect on the membrane separation process.

The antscalant dosage was selected in compliance with the manufacturer's recommendations and equaled 2 $\mathrm{mg} / \mathrm{l}$. The chemical in the calculated dosage was introduced into the initial clarified leachate. Afterwards the process of membrane separation was performed at the first stage of the pilot plant following the above described technology.

During testing the dependence of the membrane specific performance on the concentration degree was determined. The results are presented in table 4.

Table 4: Dependence of membrane specific performance changes on concentration degree using antiscalant Clarofos 381

\begin{tabular}{|c|c|c|c|c|}
\hline $\begin{array}{c}\text { Concen- } \\
\text { tration } \\
\text { period, } \\
\text { min }\end{array}$ & $\mathrm{t},{ }^{\circ} \mathrm{C}$ & $\begin{array}{c}\text { Membrane } \\
\text { element } \\
\text { perfor- } \\
\text { mance, } 1 / \mathrm{h}\end{array}$ & $\begin{array}{c}\text { Membrane } \\
\text { specific } \\
\text { perfor- } \\
\text { mance, } \\
1 / \mathrm{m}^{2} \mathrm{~h}\end{array}$ & $\begin{array}{c}\text { Concen- } \\
\text { tration } \\
\text { degree, } \\
\text { times }\end{array}$ \\
\hline 0 & 18 & 143 & 20.4 & 1 \\
\hline 10 & 18.5 & 132 & 18.8 & 1.1 \\
\hline 35 & 19 & 117 & 16.7 & 1.2 \\
\hline 50 & 19.5 & 97 & 13.8 & 1.33 \\
\hline 65 & 20 & 91 & 13 & 1.4 \\
\hline 70 & 20.5 & 84 & 12 & 1.5 \\
\hline 90 & 21 & 73 & 10.4 & 1.7 \\
\hline 105 & 21.5 & 60 & 8.6 & 1.8 \\
\hline 120 & 22 & 53 & 7.6 & 2 \\
\hline 165 & 24 & 41 & 5.8 & 2.2 \\
\hline 190 & 25 & 21 & 3.0 & 2.9 \\
\hline
\end{tabular}

The final concentration degree was in 2.9 times.
The final chemical for testing and evaluating their effect on membrane separation of the clarified landfill leachate was sodium tripolyphosphate as antiscalant.

The chemicals choice was made at random, it showed the best properties as a washing agent for working out the chemical washing modes of membrane elements after RO separation of landfill leachate. It has been suggested that sodium tripolyphosphate introduction into the initial leachate might positively affect membrane separation process in general.

During the experiments two doses of the chemical were tested $-50 \mathrm{mg} / \mathrm{l}$ and $500 \mathrm{mg} / \mathrm{l}$. The testing method completely coincides with the above described experiments. The dependence of membrane specific performance on the concentration degree at different dosage of sodium tripolyphosphate is presented in tables 5 and 6 .

Table 5: The dependence of membrane specific performance on the concentration degree at sodium tripolyphosphate concentration $50 \mathrm{mg} / \mathrm{l}$

\begin{tabular}{|c|c|c|c|c|}
\hline $\begin{array}{c}\text { Concen- } \\
\text { tration } \\
\text { period, } \\
\text { min }\end{array}$ & $\mathrm{t},{ }^{\circ} \mathrm{C}$ & $\begin{array}{c}\text { Membrane } \\
\text { element } \\
\text { perfor- } \\
\text { mance, } 1 / \mathrm{h}\end{array}$ & $\begin{array}{c}\text { Membrane } \\
\text { specific } \\
\text { perfor- } \\
\text { mance, } \\
1 / \mathrm{m}^{2} \mathrm{~h}\end{array}$ & $\begin{array}{c}\text { Concen- } \\
\text { tration } \\
\text { degree, } \\
\text { times }\end{array}$ \\
\hline 0 & 18 & 107.8 & 15.4 & 1 \\
\hline 10 & 18 & 105 & 15.0 & 1.05 \\
\hline 25 & 19 & 86.8 & 12.4 & 1.1 \\
\hline 40 & 19 & 70 & 10 & 1.2 \\
\hline 55 & 20 & 60.2 & 8.6 & 1.25 \\
\hline 85 & 21 & 49 & 7 & 1.3 \\
\hline 105 & 21 & 45.5 & 6.5 & 1.4 \\
\hline 120 & 20 & 37.8 & 5.4 & 1.5 \\
\hline 160 & 21 & 35 & 5 & 1.7 \\
\hline 180 & 22 & 30.1 & 4.3 & 1.8 \\
\hline 205 & 23 & 28 & 4 & 2 \\
\hline
\end{tabular}

The final concentration degree was in 2 times.

Table 6: The dependence of membrane specific performance on the concentration degree at sodium tripolyphosphate concentration $500 \mathrm{mg} / \mathrm{l}$

\begin{tabular}{|c|c|c|c|c|}
\hline $\begin{array}{c}\text { Concen- } \\
\text { tration } \\
\text { period, } \\
\text { min }\end{array}$ & $\mathrm{t},{ }^{\circ} \mathrm{C}$ & $\begin{array}{c}\text { Membrane } \\
\text { element } \\
\text { perfor- } \\
\text { mance, } 1 / \mathrm{h}\end{array}$ & $\begin{array}{c}\text { Membrane } \\
\text { specific } \\
\text { perfor- } \\
\text { mance, } \\
1 / \mathrm{m}^{2} \mathrm{~h}\end{array}$ & $\begin{array}{c}\text { Concen- } \\
\text { tration } \\
\text { degree, } \\
\text { times }\end{array}$ \\
\hline 0 & 18 & 143 & 20.4 & 1 \\
\hline 10 & 18 & 126 & 18 & 1.05 \\
\hline 30 & 18 & 115 & 16.4 & 1.2 \\
\hline 60 & 19 & 94 & 13.4 & 1.3 \\
\hline 75 & 20 & 76 & 10.9 & 1.4 \\
\hline 85 & 20 & 69 & 9.8 & 1.5 \\
\hline 95 & 21 & 53 & 7.6 & 1.7 \\
\hline 110 & 21 & 50 & 7.2 & 1.8 \\
\hline 125 & 22 & 43 & 6.1 & 2 \\
\hline
\end{tabular}

The final concentration degree was in 2 times. 
The graphic dependence of RO membrane specific performance on concentration degree when using various types of antiscalants is shown in figure 2.

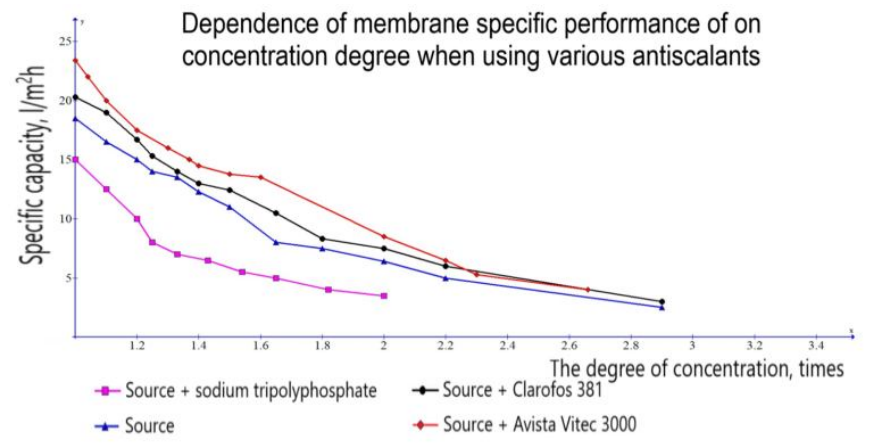

Figure. 2. Dependence of membrane specific performance of on concentration degree when using various antiscalants

The graphics dependency shown in Fig.3 demonstrates that among the studied chemicals antiscalants Avista Vitec 3000 revealed the best results for increasing the membrane specific performance in treating the clarified landfill leachate. Sodium tripolyphosphate introduction into the initial waste water produces a noticeable positive impact on RO separation only at high dosage, but here rises the question of its economic feasibility.

\section{CONCLUSIONS}

The antiscalant introduction prior to reverse osmosis membrane separation of pre-treated waste water with increased hardness undoubtedly positively affects the membrane specific performance, thus significantly increasing it.

When choosing a specific brand of antiscalant, it is necessary to take into account the characteristics of the fed water composition, equipment operating mode and special requirements of the treatment technology.

\section{ACKNOWLEDGMENTS}

This work was financially supported by project No. 05.607.21.0314 by the Ministry of Science and Higher Education of the Russian Federation (Agreement dated 06.12.2019 No. 075-15-2019-1837) within the framework of the Federal Target Program "Research and Development in Priority Directions for the Development of the Russian Science and Technology Complex for 2014-2020".

The research results were obtained using the scientific equipment of the collective use center "Interregional multidisciplinary and interdisciplinary center for the collective use of promising and competitive technologies in the areas of development and application of domestic achievements in the field of nanotechnology in industry / engineering".

\section{REFERENCES}

1. E.W. Tow, D.M.Warsinger, A.M. Trueworthy, J. Swaminathan, G.P. Thiel, S.M. Zubair, A.S. Mayerson, J. H. Lienhard V. "Comparison of fouling propensity between reverse osmosis, forward osmosis, and membrane distillation." Journal of Membrane Science. 2018. Vol. 556, pp. 352-364.

https://doi.org/10.1016/j.memsci.2018.03.065

2. S. F. Anis, R. Hashaikeh, N. Hilal "Reverse osmosis pretreatment technologies and future trends: A Comprehensive review.” Desalination. 2019. Vol. 452. № 15. pp. 159-195. https://doi.org/10.1016/j.desal.2018.11.006

3. J. Kavitha, M. Rajalakshmi, A. R. Phani, M. Padaki "Pretreatment processes for seawater reverse osmosis desalination systems - A review." Journal of Water Process Engineering. Vol.32, December 2019, 100926.

https://doi.org/10.1016/j.jwpe.2019.100926

4. M. Badruzzaman, N.Voutchkov, L. Weinrich, J. G. Jacangelo "Selection of pretreatment technologies for seawater reverse osmosis plants: A review."Desalination. 2019. Vol. 449. pp. 78-81.

https://doi.org/10.1016/j.desal.2018.10.006

5. T.A. Trifonova, S.I. Roschina, L.A. Shirkin, O.G. Selivanov, M.E. Ilina "An integrated innovative technology for the treatment of municipal solid waste landfill leachate." Biosciences Biotechnology Research Asia. 2015, Vol.12, № 3, pp. 2481-2488.

https://doi.org/10.13005/bbra/1927

6. T.A. Trifonova, L.A. Shirkin, O.G. Selivanov, M.E. Ilina "Assessment of Aqueous Solutions Concentration Efficiency of Mineral Salts and Organic Media Applying Rotary-Film Evaporator for Natural and Waste Water Treatment." International Journal of Emerging Trends in Engineering Research. 2019, Vol.7, № 12, pp. 857-860.

https://doi.org/10.30534/ijeter/2019/227122019

7. S. Jiang Y. Li, B. P. Ladewig "A review of reverse osmosis membrane fouling and control strategies." Science of The Total Environment. 2017. Vol. 595. pp. 567583.

https://doi.org/10.1016/j.scitotenv.2017.03.235

8. T.A. Trifonova, A.A. Povorov, L.A. Shirkin, O.G. Selivanov, M.E. Ilina "Evaluating Membrane Separation Effectiveness for Highly Concentrated Aqueous Media Applying Two-stage Reverse Osmosis Plant." International Journal of Emerging Trends in Engineering Research. 2020, Vol.8, № 3, pp. 906-910 .

https://doi.org/10.30534/ijeter/2020/47832020 